УДК 378.18

DOI 10.23951/2307-6127-2020-2-44-51

\title{
ПЕДАГОГИЧЕСКИЙ ПОТЕНЦИАЛ ОБЪЕКТНОЙ КЛАССИФИКАЦИИ СОВРЕМЕННЫХ ЛИТЕРАТУРНЫХ ЭКСКУРСИЙ
}

\section{Т. В. Галкина}

Томский государственный педагогический университет, Томск

Необходимость выявления и осмысления педагогического потенциала литературных экскурсий обусловлена потребностью формирования компетенций будущего педагога, направленных на использование окружающей среды в качестве образовательного и воспитательного пространства. При этом необходимо различать педагогический потенциал каждого экскурсионного объекта исходя из его функциональных характеристик. Предлагаемая объектная классификация литературных экскурсий, критерием которой выступает персонификация формирующих содержание экскурсии объектов, позволяет выделить три группы объектов: прижизненные, послежизненные и искусственные. Следуя функциональным характеристикам этих объектов (у прижизненных - подлинность, у послежизненных - мемориальность, увековечение памяти, у искусственных - досуг), предлагается создавать комплекс литературных экскурсий. Такой комплексный подход позволяет узучать жизнь и творчество литераторов, погружаясь сначала в биографические материалы (прижизненные объекты: дома, квартиры, музеиусадьбы, музеи-заповедники), затем в эстетику мемориальных памятников и некрополей (послежизненные объекты) и знакомясь с воссозданными фантазиями (искусственные объекты: тематические парки под открытым небом и музеи). Таким образом, путь осмысления педагогического потенциала различных литературных экскурсий (литературно-биографических, историко-литературных, литературно-краеведческих, литературно-художественных) будет способствовать формированию духовного мировоззрения будущего педагога.

Ключевые слова: литературная экскурсия, объектная классификаиия, педагогический потенциал литературной экскурсии, подготовка кадров.

Одной из главных педагогических задач современного образования является актуализация среды непрерывного развития личности (ребенка, подростка, студента, педагога), опирающаяся на деятельностный подход. При этом неотъемлемой частью данной среды является окружающая среда не только локального социума, но и пространственная среда (села, города, страны). Познание окружающей среды посредством экскурсий представляет собой системный образовательный процесс в учебное и внеучебное время, существенно дополняющий федеральный государственный образовательный стандарт. По мнению О. И. Угриновой, образовательная экскурсия - это педагогический метод, позволяющий преобразовать действительность в среду развития личности студента посредством актуализации объектов окружающего мира - выявление их культурных смыслов, значений и образов [1].

Образовательная литературная экскурсия, посвященная знакомству с жизнью и творчеством выдающихся писателей и поэтов, является одним из самых распространенных подвидов современного туризма. Популярность литературных экскурсий в России и за рубежом обусловлена присущим им комплексом биографических, исторических, художественных и краеведческих материалов. По сложившейся в российском экскурсоведении тради- 
ции литературные экскурсии принято делить на литературно-биографические (монографические), историко-литературные (обзорные), литературно-художественные (поэтико-текстовые) и литературно-краеведческие [2, с. 15]. Однако развитие типов экскурсионного обслуживания в последнее десятилетие позволяет говорить о наличии некоторых изменений, напрямую связанных со структурой содержания литературных экскурсий.

В связи с этим целью настоящего исследования является выявление новых классификационных основ в отношении современных литературных экскурсий. Для достижения поставленной цели предлагается классификация литературных экскурсий. Ее критерием выступает персонификация объектов, формирующих содержание экскурсии, которые разделены на три группы: прижизненные, послежизненные и искусственные.

На первом месте в данной классификации закономерно стоят прижизненные объекты как реальная среда жизнеобитания и творческой жизнедеятельности писателя (поэта). Мемориальные объекты позволяют взглянуть глазами писателя на окружающее пространство - реально существующие объекты (дом, усадьба, квартира, где родился и жил писатель). Начиная литературную экскурсию с места рождения писателя (поэта) необходимо проверять сведения о современной сохранности и подлинности объекта. Ценными объектами в данном случае являются домик Чехова в Таганроге в небольшом флигеле (ул. Чехова, 69), в котором в 1860 г. родился Антон Павлович, а также московская Мариинская больница для бедных, где в 1821 г. родился Ф. М. Достоевский, и дом в с. Сростки Бийского района Алтайского края, где провел детские и юношеские годы В. М. Шукшин. Однако, к сожалению, не сохранились здания, связанные с рождением А. С. Пушкина (в Москве на углу Малой Почтовой улицы и Госпитального переулка) и М. Ю. Лермонтова (в Москве в доме напротив Красных ворот). В настоящее время на эти места указывают постамент с головой юного Пушкина (скульптор Е. Ф. Белашова), установленный рядом с московской школой № 345 им. А. С. Пушкина по ул. Баумановской, 40, и мемориальная доска на высотном здании с надписью «На этом месте находился дом, где 3 (15) октября 1814 г. родился великий русский поэт Михаил Юрьевич Лермонтов». В таких случаях литературную экскурсию можно начинать с памятной доски, указывающей на место рождения, как, например, в усадьбе «Ясная Поляна» (Щекинский район Тульской области), где есть табличка с указанием места рождения Л. Н. Толстого (хотя сам дом не сохранился), или в Орле, где обозначается место рождения в 1818 г. И. С. Тургенева.

Особую достоверность жизненной среде придают подлинные предметы, среди которых жил и творил писатель например у Пушкина в Михайловском - бронзовая чернильница с арапчонком на столе; у Толстого в Хамовниках - стол, огражденный с трех сторон небольшими перильцами, и т. д. Представляется, что кабинет писателя (поэта) - это сугубо личное комфортное пространство его неустанного труда, глубоких раздумий, безутешных страданий и ослепительных побед, из которых рождались великие шедевры, покорившие человеческие души - это самобытная творческая «мастерская» писателя станет для экскурсантов своеобразным «открытием» вдохновенного мира и понимания великого писателя.

Мемориальные объекты, в том числе писательские кабинеты, лучше всего сохранились в музеях-заповедниках и музеях-усадьбах. К таким объектам в России относятся следующие музеи-заповедники: Государственный мемориальный историко-литературный и природно-ландшафтный музей-заповедник А. С. Пушкина «Михайловское» в Пушкиногорском районе Псковской области, Государственный литературно-мемориальный и природный музей-заповедник А. С. Пушкина «Болдино» в Нижегородской области, Государственный историко-культурный и природный музей-заповедник «Хмелита» А. С. Грибоедова в Вяземском районе Смоленской области, Государственный историко-литературный и при- 
родный музей-заповедник А. А. Блока «Шахматово» в Солнечногорском районе Московской области, Литературный музей-заповедник «Аксаково» С. Т. Аксакова в Бугурусланском районе Оренбургской области, Государственный мемориальный и природный музейзаповедник «Спасское-Лутовиново» И. С. Тургенева в Мценском районе Орловской области, Государственный музей-заповедник «Тарханы» М. Ю. Лермонтова в Белинском районе Пензенской области, Государственный литературно-мемориальный музей-заповедник «Мелихово» А. П. Чехова в Чеховском районе Московской области, Государственный литературно-мемориальный музей-заповедник «Кара́биха» Н. А. Некрасова в Ярославском районе Ярославской области, Всероссийский мемориальный музей-заповедник В. М. Шукшина в селе Сростки Бийского района Алтайского края; музеи-усадьбы: музейусадьба Л. Н. Толстого «Ясная Поляна» в Щекинском районе Тульской области, музейусадьба «Красный Рог» А. К. Толстого в Почепском районе Брянской области, музейусадьба А. Н. Толстого в Самаре, музей-усадьба Ф. И. Тютчева «Овстуг» в Жуковском районе Брянской области.

В отличие от музеев-заповедников и музеев-усадеб, в которых сконцентрированы целые комплексы прижизненных объектов личности и которых, к сожалению, не так много в России, существуют многочисленные литературно-мемориальные музеи, расположенные в отдельных прижизненных объектах (домах и квартирах), служивших писателю или поэту определенное время. Такие литературно-мемориальные музеи как особый тип литературного монографического музея демонстрируют прижизненные вещи писателя. К таким литературно-мемориальным музеям относятся дом-музей А. Н. Островского в Москве, доммузей Н. С. Лескова в г. Орле, дом-музей А. П. Чехова в г. Ялте, дом-музей В. П. Астафьева в пос. Овсянка Красноярского края и др. Наличие таких музеев в России позволяет проследить жизненный и творческий путь писателей, оставивших память о себе в разных населенных пунктах страны. Так, в России (помимо музея-заповедника А. С. Пушкина «Михайловское») ныне имеются четыре музея, посвященных жизни и творчеству великого поэта (мемориальный музей-лицей в Царском Селе, мемориальная квартира А. С. Пушкина на Арбате в Москве, музей-заповедник «Болдино» в Нижегородской области, музей-квартира Пушкина на Мойке в Санкт-Петербурге).

Необходимо оговориться, что часто отдельные прижизненные объекты становятся основой создания литературно-мемориальных музеев. Так, литературно-мемориальный музей И. А. Бунина в г. Ельце размещен в доме, где будущий писатель жил во время учебы в гимназии в 1883-1886 гг., музей «Волшебная страна» им. А. М. Волкова Томского государственного педагогического университета был открыт в 2002 г. в здании Томского учительского института, в котором Александр Волков учился в 1907-1910 гг., а литературный музей Ф. М. Достоевского открыт в 1983 г. в г. Омске в комендантском доме. Музеефикация этих объектов позволяет включать их как в историко-литературные («Русская литература XIX в.»), так и в литературно-биографические экскурсии («Бунинские места в Ельце», «Детский писатель Александр Волков в Томске», «Достоевский и г. Омск»).

Своего рода «прижизненным» пространством литератора являются природные объекты вокруг их мест жительства (домов, усадеб). Так, описания природы во многих произведениях Пушкина напрямую связаны с его пребыванием в селах Михайловское: стихотворение «...Вновь я посетил тот уголок земли...», картины русской природы в романе «Евгений Онегин»; Болдино, где было написано стихотворение «Осень». В творчестве Лермонтова природа как объект восприятия раскрывается в произведениях «Прекрасны вы, поля земли родной...», «Родина», «Солнце осени». Для Льва Толстого природное пространство Ясной Поляны (пруды, яблоневые сады, рощи, поляны, парки) было любимым местом прожива- 
ния, тем более что Лев Николаевич и Софья Андреевна Толстые, а также их дети сами посадили 300 тысяч берез, дубов и елок в Ясной Поляне, создав рукотворные леса и рощи [3].

Следовательно, при наличии природных объектов, составляющих прижизненное пространство литераторов, возникает насущная необходимость их включения в маршрут литературной экскурсии. Сочетание природного и архитектурного компонентов в одной экскурсии позволит создать цельный образ прижизненного пространства писателя (поэта) с присущими ему личностными характеристиками, выраженными в его творческом наследии.

Посещение музеев-заповедников, музеев-усадеб и домов-музеев выдающихся писателей и поэтов как в России, так и за рубежом необходимо сделать неким обязательным (базовым) компонентом культурного развития личности будущего педагога, особенно будущих учителей русского языка и литературы. Как известно, Гёте приписывают такие слова: «Если хочешь понять поэта, побывай на его родине». При этом на человека воздействует не только мемориальная бытовая среда, включающая прижизненные объекты личности и таким образом визуализирующие его биографию, но и природный ландшафт окружающей местности, который также предстает неким узнаваемым биографическим компонентом. Все это позволяет как бы «вжиться» в родовую, временную и пространственную атмосферу личности писателя (поэта). Именно в таких мемориальных объектах среди бесценных вещей начинают закладываться аксиологические основы личного «знакомства» с выдающимся писателем, позволяющие заглянуть в его сокровенный мир, сопереживать написанным им строкам, по-новому прочитать и глубже прочувствовать некий тайный смысл его трогательных писем. Это личное «знакомство» раскрывает писателя не только в профессиональном смысле, но и как гражданина, друга, семьянина, охватывая, таким образом, всю многомерность человеческой личности, нацеленной на вдохновенное творчество.

К прижизненным объектам, которые видел сам писатель и которые он описал в своих произведениях, соединяющих в единое целое биографию и творчество, относятся реальные объекты селитебной и природной зон. Использование этих объектов в литературных экскурсиях дало новый толчок к популяризации творчества многих известных литераторов. Так, Москва с Патриаршими прудами, рестораном «Грибоедов», «нехорошей квартирой» популярна среди поклонников романа М. А. Булгакова «Мастер и Маргарита»; Дублин (Ирландия) притягателен маршрутом по следам главного героя романа Джеймса Джойса «Улисс» (при этом по пути следования установлены памятные таблички с цитатами из книги); прогулки по Манхэттену (США) привлекают знатоков романа Джерома Д. Сэлинджера «Над пропастью во ржи»; в Стокгольме (Швеция) приглашают на пеший экскурсионный тур по трилогии Стига Ларссона «Миллениум»; в Японии популярен маршрут по роману Харуки Мураками «Норвежский лес»; Париж славится как классическими литературными маршрутами по следам героев «Собора Парижской Богоматери» и «Отверженных» Виктора Гюго или персонажей из «Истории тринадцати» и «Банкирского дома Нусингена» Оноре де Бальзака, так и новыми маршрутами по следам героев «Кода да Винчи» американского писателя Дэна Брауна.

Не только города, но страна и даже страны стали объектами литературных экскурсий. От города Толедо до небольшого городка Атьенсе (Испания) проходит маршрут путешествия героя Сервантеса Дон Кихота, а маршрут бравого солдата Швейка (Ярослава Гашека) пересекает Чехию, Австрию, Венгрию, Словакию, Польшу и Украину. При этом нередко само литературное произведение получает новый статус: становится маршрутным путеводителем, а при осмотре очередного объекта экскурсии участниками воспроизводится (зачитывается) описание этого объекта из соответствующего романа. Такое чтение отдельных страниц романа на улицах и площадях группами людей можно считать «народной методикой», развивающей методические основы экскурсионной деятельности. 
Важность включения в маршрут литературной экскурсии так называемых послежизненных объектов объясняется искренним желанием почтить память любимого поэта или писателя, завершившего свой жизненный путь. К послежизненным объектам относятся отдельные объекты некрополя (места погребения). Местами паломничества в России стали Святогорский монастырь со скромной могилой Пушкина (пос. Пушкинские Горы в Псковской области); с. Тарханы (Пензенская область), где находится могила Лермонтова; городское кладбище в г. Старый Крым, где покоится Александр Грин; с. Овсянка (Красноярский край), где можно поклониться Виктору Астафьеву, и многие другие места погребения.

Особыми послежизненными объектами экскурсионного показа в качестве объектов культурного наследия являются кладбища, которые можно включать не только в литературно-биографическую экскурсию, посвященную жизни и творчеству отдельного литератора, но и в тематические историко-литературные или литературно-краеведческие экскурсии. К таким объектам относятся столичные кладбища: «Литераторские мостки» Волковского кладбища в Санкт-Петербурге, где похоронены В. Г. Белинский, Н. А. Добролюбов, Д. И. Писарев, И. С. Тургенев, М. Е. Салтыков-Щедрин, Н. С. Лесков, Г. И. Успенский, С. Я. Надсон, А. И. Куприн, Н. Г. Помяловский, А. А. Блок, И. А. Гончаров [4], московское Новодевичье кладбище с надгробиями Н. В. Гоголя, А. П. Чехова, М. А. Булгакова, В. В. Маяковского, В. Хлебникова, В. Я. Брюсова, А. Н. Толстого, А. А. Фадеева, А. А. Вознесенского, а также московское Ваганьковское кладбище с надгробиями С. А. Есенина, Б. Ш. Окуджавы, В. С. Высоцкого и др.

К послежизненным объектам экскурсионного маршрута литературной экскурсии относятся монументальная скульптура (памятники), воплощающая объемный образ литератора в различном материале (мраморе, граните, бронзе). Так, первый бронзовый памятник Пушкину (скульптор А. М. Опекушин) был установлен в 1880 г. в Москве, а в Ленинграде памятник Пушкину (скульптор М. К. Аникушин) украсил площадь Искусств в 1957 г. При этом необходимо добавить, что статуи и бюсты Пушкина установлены почти в каждом городе России, а также в 46 странах мира, признающих мировое значение творчества великого русского литератора [5]. Первый памятник Лермонтову (скульптор А. М. Опекушин) был открыт в 1889 г. в г. Пятигорске, остальные смь памятников и бюстов этому поэту появились позднее в Москве, Санкт-Петербурге, Тарханах, Грозном, Кисловодске, Пензе и Тамани. Памятники Достоевскому стали активно возводиться с 1990-х гг. в Москве, Санкт-Петербурге, Омске, Старой Руссе, Тобольске, а также в Германии, Болгарии, Эстонии. Монументальная скульптура в качестве послежизненного объекта в структуре литературной экскурсии выступает как достаточно распространенный и аттрактивный объект экскурсионного показа и может существенно дополнять визуальный компонент литературной экскурсии.

Однако необходимо понимать, что комплексный подход позволяет объединять в одной экскурсии и разные категории объектов. Связь прижизненных и послежизненных объектов в одной экскурсии представляет собой некий синтез биографического материала (вместе с реально существующими объектами окружения литератора) и отрефлексированного современным поколением осознания значимости творчества литератора в памятниках и объектах некрополя. В этом контексте важно именно на прижизненных и послежизненных объектах выявить развитие и расцвет таланта литератора как личности и творца, осмысленно выбравшего для себя эту стезю. Ярким примером такой экскурсии, которую совершили студенты Томского государственного педагогического университета в 2012 г., является посещение пушкинских мест на Псковщине: сел Михайловского, Петровского и Тригорского и после этого - знаменитой могилы А. С. Пушкина в Святогорском монастыре. 
Следующая категория объектов в предложенной классификации литературных экскурсий включает искусственные объекты, которые могут быть как прижизненными, так и послежизненными. Выделение искусственных объектов в отдельную категорию обусловлено тем, что они связаны, как правило, не с биографией, а с творчеством литераторов. Искусственные объекты выступают в качестве неких воплощений фантазий литераторов, описанных в их произведениях. При этом такими объектами могут стать новоделы или приспособленные (пригодные, тождественные) реальные объекты, приобретающие таким образом новый смысловой оттенок.

Ярким примером создания искусственных экскурсионных объектов является «Мир Астрид Линдгрен» - парк, расположенный в пяти километрах от родного города Астрид Линдгрен Виммербю (Швеция) [6]. В этом парке по описаниям писательницы построен целый городок, где живут любимые персонажи Карлсон, Пеппи Длинный чулок и др. При этом, по задумке архитекторов, выстроены совсем не большие домики, а детские, в некоторые из них можно войти; также в городке имеется маленький зоопарк. По расписанию на нескольких театральных площадках взрослыми и детьми разыгрываются интересные представления, придуманные Астрид Линдгрен. Парк как воплощенная в жизнь фантазия знаменитой шведской писательницы вместе с живыми персонажами стал реальным местом бытования литературного наследия Линдгрен. Этот парк пользуется огромной мировой популярностью у детей и взрослых и является эффективным туристическим объектом, который ежегодно посещают более 350 тыс. человек. В этом отношении Швеции принадлежит безусловное мировое первенство как в музеефикации историко-культурных объектов (музей под открытым небом «Скансен», 1891 г.), так и в создании искусственных музейных объектов под открытым небом (парк «Мир Астрид Линдгрен», 1981 г.).

Наряду с новоделами к искусственным объектам литературных экскурсий относятся реальные объекты, не связанные с биографией или творчеством литератора, но представляемые экскурсантам как фантазийные объекты из литературных произведений. Так, благодаря популярности романов о Гарри Потере английской писательницы Джоан Роулинг в Великобритании появились новые литературные экскурсии и достопримечательности (платформа № 93/4 на лондонском вокзале Кингс-Кросс (King’s Cross), Оксфордский университет представляется как школа волшебства Хогвартс, а также в экскурсию включен старинный рынок Лондона - Лиденхолл-маркет в роли Косого переулка) [7], а для музея знаменитого Шерлока Холмса в Лондоне было отведено специальное здание и установлен адрес, данный Артуром Конан-Дойлем - Бейкер-стрит, 221b [8]. Искусственные экскурсионные объекты востребованы разновозрастной аудиторией, но особенно детско-юношеской аудиторией с повышенными требованиями к доступности и интерактивности.

Таким образом, объектная классификация литературных экскурсий позволяет четко выделять педагогический потенциал объектов исходя из их функциональных характеристик. Прижизненные объекты в литературных экскурсиях являются, несомненно, самыми ценными объектами, воспроизводящими вещественно-визуальный жизненный мир выдающегося писателя или поэта и оказывающими наибольшее влияние на формирование собственного отношения к богатому мировому литературному наследию. Поэтому желание побывать на родине великих литераторов необходимо закладывать в души будущих педагогов как стремление к непрерывному образованию и совершенствованию, повышению своего профессионализма на долгие годы. В свою очередь, послежизненные объекты в литературной экскурсии позволяют воссоздать весь жизненный и творческий путь литератора и служат неким эстетическим обрамлением экскурсии, а искусственные объекты завершают знакомство с литературным наследием в увлекательных и интерактивных формах. 
Решая проблему овладения молодежью мировым литературным наследием, объектная классификация позволяет изучать жизнь и творчество литераторов, погружаясь сначала в биографические материалы (прижизненные объекты), потом в эстетику мемориальных памятников и некрополей (послежизненные объекты) и, наконец, знакомясь с воссозданными творческими фантазиями (искусственные объекты). Такой комплексный подход к изучению жизни и творчества великих литераторов в литературно-биографических, историко-литературных, литературно-краеведческих, литературно-художественных и досуговых экскурсиях позволит более качественно реализовать педагогический потенциал в познавательном, образовательном, воспитательном и досуговом смыслах. В идеальном варианте учителям необходимо изыскивать возможности уже в школьные годы (в каникулярное время) выводить и вывозить детей на литературные экскурсии как в родном городе, так и организуя поездки по России. А родителям, бывая с детьми за границей, посещать не только досуговые достопримечательности, но и целенаправленно знакомить детей с историческим и культурным наследием посещаемой страны, в том числе и с мемориальными местами, домами-музеями великих писателей и поэтов. Молодой педагог на основе личных переживаний и впечатлений сможет поделиться накопленным литературным багажом с детьми, заложив в них эмоциональные и духовные скрепы.

\section{Список литературы}

1. Угринова О. И. Образовательная экскурсия как метод освоения культурного наследия студентами педагогического колледжа на занятиях дисциплин культурологического цикла. URL: https:/www.metod-kopilka.ru/ obrazovatelnaya_ekskursiya_kak_metod_osvoeniya_kulturnogo_naslediya_studentami_pedagogicheskogo-40332. $\mathrm{htm} /$ (дата обращения: 18.10.2019).

2. Савина Н. В., Горбылева 3. М. Экскурсоведение. Минск: БГЭУ, 2004. 354 с.

3. Тимофеева Л. Толстой покупал березы на гонорар от «Войны и мира». URL: https://myslo.ru/city/tula/tulyaki/ tolstoy-pokupal-berezi-na-gonorar-ot-voyni-i-mira/ (дата обращения: 17.10.2019).

4. Литераторские мостки. URL: https://ru.wikipedia.org/wiki/Литераторские_мостки/ (дата обращения: 17.10.2019).

5. Памятники Пушкину. URL: https://ru.wikipedia.org/wiki/Памятники_A._C._Пушкину\#Москва/ (дата обращения: 17.10.2019).

6. Мир Астрид Линдгрен. URL: https://ru.wikipedia.org/wiki/Мир_Астрид_Линдгрен/ (дата обращения: 24.10.2019).

7. Литературные маршруты для туристов. URL: http:/www.travel.ru/news/2012/06/12/201902.html/ (дата обращения: 25.10.2019).

8. Музей Шерлока Холмса. URL: https://ru.wikipedia.org/wiki/Музей_Шерлока_Холмса/ (дата обращения: 25.10.2019).

Галкина Татьяна Васильевна, кандидат исторических наук, доцент, декан историко-филологического факультета, Томский государственный педагогический университет (ул. Киевская, 60, Томск, Россия, 634061). E-mail: galkinat@sibmail.com

Материал поступил в редакцию 06.11.2019.

DOI 10.23951/2307-6127-2020-2-44-51

\section{PEDAGOGICAL POTENTIAL OF OBJECT CLASSIFICATION OF MODERN LITERARY EXCURSIONS}

\section{T. V. Galkina}

Tomsk State Pedagogical University, Tomsk, Russian Federation

The need to identify and understand the pedagogical potential of literary excursions is based on the need to form the scope of competence for future teachers which is aimed at using the environment as an educational space. It is necessary to distinguish the pedagogical potential of each excursion object on the basis of its functional characteristics. The suggested object classification of literary excursions, the criterion of which is the object personification 
forming the excursion content, allows dividing these objects into three groups: lifetime, afterlife and artificial objects. It is suggested to create a complex of literary excursions following functional characteristics of these objects (lifetime - authenticity, afterlife memorialization, artificial - leisure). This complex approach allows to study the life and work of writers plunging first into biographical materials (lifetime objects: houses, apartments, estate museums, reserve museums), then into the aesthetics of memorial monuments and necropolises (afterlife objects) and, finally, into getting to know recreated fantasies (artificial objects: open-air theme parks, museums). Thus, the way of pedagogical potential understanding of various literary excursions (literary and biographical, historical and literary, literary and regional, literary and artistic) will contribute to the spiritual world view formation of future teachers.

Keywords: literary excursion, object classification, pedagogical potential of literary excursion, training in university.

\section{References}

1. Ugrinova O. I. Obrazovatel'naya ekskursiya kak metod osvoyeniya kul'turnogo naslediya studentami pedagogicheskogo kolledzha na zanyatiyakh distsiplin kul'turologicheskogo tsikla [Educational tour as a method of developing the cultural heritage of students of pedagogical College in the classroom disciplines of the cultural cycle] (in Russian). URL: https://www.metod-kopilka.ru/obrazovatelnaya_ekskursiya_kak_metod_osvoeniya_ kulturnogo_naslediya_studentami_pedagogicheskogo-40332.htm/(accessed 18 October 2019).

2. Savina N. V., Gorbyleva S. M. Ekskursovedeniye [Tour guidance]. Minsk, BSEU Publ., 2004. 354 p. (in Russian).

3. Timofeyeva L. Tolstoy pokupal berezy na gonorar ot «Voyny i mira» [Tolstoy bought birch with the money from «War and Peace»] (in Russian). URL: https://myslo.ru/city/tula/tulyaki/tolstoy-pokupal-berezi-na-gonorar-ot-voyni-i-mira/ (accessed 17 October 2019).

4. Literatorskiye mostki [Literary bridges] (in Russian). URL: https://ru.wikipedia.org/wiki/Литераторские_ мостки/ (accessed 17 October 2019).

5. Pamyatniki Pushkinu [Monuments to Pushkin] (in Russian). URL: https://ru.wikipedia.org/wiki/ Памятники_А._С._Пушкину\#Москва/ (accessed 17 October 2019).

6. Mir Astrid Lindgren [Astrid Lindgren's World] (in Russian). URL: https://ru.wikipedia.org/wiki/Мир_Астрид_ Линдгрен/ (accessed 24 October 2019).

7. Literaturnye marshruty dlya turistov [Literary routes for tourists] (in Russian). URL: http://www.travel.ru/ news/2012/06/12/201902.html/ (accessed 25 October 2019).

8. Muzey Sherloka Holmsa [Sherlock Holmes Museum] (in Russian). URL: https://ru.wikipedia.org/wiki/Музей_ Шерлока_Холмса/ (accessed 25 October 2019).

Galkina T. V., Tomsk State Pedagogical University (ul. Kiyevskaya, 60, Tomsk, Russian Federation, 634061). E-mail: galkinat@sibmail.com 